\title{
Inhibiting Factors in the Strategic Financial Management Decision Making Process: Evidence from South African SMMEs
}

\section{Seraphin Kengne}

Cacfis Africa Consulting

\section{Doi:10.5901/mjss.2015.v6n2p113}

\section{Abstract}

The purpose of this article is to uncover the principal obstacles preventing small business owner managers from making sound strategic financial management decisions. These obstacles are generally related to the owner managers' reluctance to follow accepted theoretical norms (steps) in terms of information search and analysis. This reluctance is attributable to the decision makers' significant lack of knowledge and experience. Data gathered with a structured questionnaire was based on a sample of 143 small business owner managers registered with SEDA (Small Enterprise Development Agency) in South Africa. The results point to an absence of a proper theoretical framework for gathering and analysing information necessary for effective decision making. This framework commonly entails elements such as experience and techniques acquired from time spent in business and business intuition. Recommendations are made to assist small business owner managers to improve on their strategic decision making and resource allocation processes.

Keywords: Inhibiting factors, small business owner manager, SMME's strategic financial management decisions, South Africa.

\section{Introduction}

South Africa has a relatively high unemployment rate, low economic growth and dismal performance of small businesses (Chimucheka, 2014:403). Governments and local communities worldwide have recognized that entrepreneurs and small businesses are key to building prosperity and to stimulate economic growth (Fatoki, 2014:100). Globally, entrepreneurs and small businesses are regarded as the economic engine necessary for growth, poverty alleviation, and job creation (Smith \& Chimucheka, 2014:160). Orobia et al. (2013:127) agree that small businesses greatly contribute to the economic development of a country, and their contribution can be gauged in terms of job creation, income generation, and poverty reduction.

The main obstacles to growth and survival of SMEs are related to financial decision making (Olawale \& Garwe, 2010:729; Fatoki, 2012:179). Effective strategic financial management decision making is thus an important aspect with which most small business owner managers' battle. The aim of this article is to investigate the issues in this connection.

\section{Problem Statement}

Jocumsen (2004:669) argues that small businesses do not follow the necessary theoretical steps in terms of information search and analysis, risk and option consideration. This explains why the decision making process in small business is much less complex than suggested by theoretical models (Huang 2009:87). Little has been done in the literature to date to explain this anomalous practice in small business. Many studies tend to focus on the functions within small businesses, explaining or describing the mechanisms by which they arrive at final decisions (Liberman-Yaconi, Hooper \& Hutchings 2010:88).

This study goes beyond this, and tackles the principal reason why most small businesses do not practice the theory. According Ekanem (2005:307), as well as to Mair and Thompson (2009:401), decision makers tend to focus more on the event than on the process. There is an unconscious motion through the process, without due consideration of the actual steps to the final decision. A number of factors closely associated with this phenomenon emerge, including the small business owner manager age, gender, educational qualification, training and experience.

\section{The Objective of the Study}

The objective of this article is to investigate and describe the main inhibiting factors that detract from effective and 
efficient financial management decision making in small businesses. These factors tend to centre on the owner manager himself, as the main driver of the business.

\section{Literature Review}

Literature on financial management identifies the principal factors that lead to inefficiency in strategic financial management decisions. An analysis of these inefficiencies, carried out by Harif, Osman and Hoe (2010:17), reveals a need for a more in-depth examination of the problem. Broadly, four classes of factors emerge: the human, as the business driver (Agyei-Mensah, 2011:3781), the business itself (Botha \& Esterhuyzen, 2013: 331), the financial management practices (Fatoki, 2012:180), and the relevant sourrending issues (Perks, 2010:229).

\subsection{Financial management}

Literature on financial management of small business identifies the elements critical to effective strategic decisions making.

\subsubsection{Financial management practices}

Financial management practices in the SMMEs sector have long attracted the attention of several researchers across the world. Depending on different objectives, researchers emphasize different aspects of financial management practices. Studies by McMahon et al. (1993) and McMahon (1998) summarise their review of financial management practices in Australia, the UK, and the USA. Studies by Agyei - Mensah (2011:3793) and Sunday (2011:271) focus on financial management practices in Africa, whilst those by Netswera (2001:31), Perks (2010:220), Fatoki (2012:179; 2014:104), Smith and Chimucheka (2014:160), Neneh (2012:3365), and Chimucheka (2014:403) emphasize financial management practices in South Africa. Financial management practices include accounting information systems, financial reporting, working capital management, financial structure management, financial planning and control, as well as financial advice and financial management expertise.

Relevant to this article are selected financial management practices related to SMMEs strategic financial management decision making. These include accounting information systems, financial reporting and analysis, working capital management, and financial planning and control.

\subsubsection{Financial management decisions}

Different types of financial management decisions are encountered in small businesses, three of which are highlighted by Ang (1992:1): (1) investment decisions, (2) financing decisions, and (3) dividend decisions. Whereas McMahon (1995:1) supports this contention of the three main decision types based on a view of the balance sheet, Ross, Westerfield and Jaffe (1999:1) consider, in addition to the financing decision, budgeting and working capital management decisions to be of strategic importance. Anderson and Atkins (2001:311) distinguish between two main categories of strategic decisionmaking: the programmed problems decisions and the non-programmed.

The programmed problems decisions are those generally made by supervisory or middle management staff in an organization. They tend to be routine and repetitive in nature, occurring in well-structured situations. In contrast, nonprogrammed problems decisions are unique, non-recurring, and often require the expertise of top-level management. These latter decisions require a custom-made response and need automated decision support systems (DSS). They are called strategic decisions (see figure 1 below).

\subsection{Human (decision makers)}

It is very important to distinguish between entrepreneur and ordinary business owner manager. Nieman and Pretorius (2004:14) argue that ordinary business managers are not dominant in their fields and are rarely engaged in any innovative and risk taking actions. 
Figure 1: Decision making - Levels

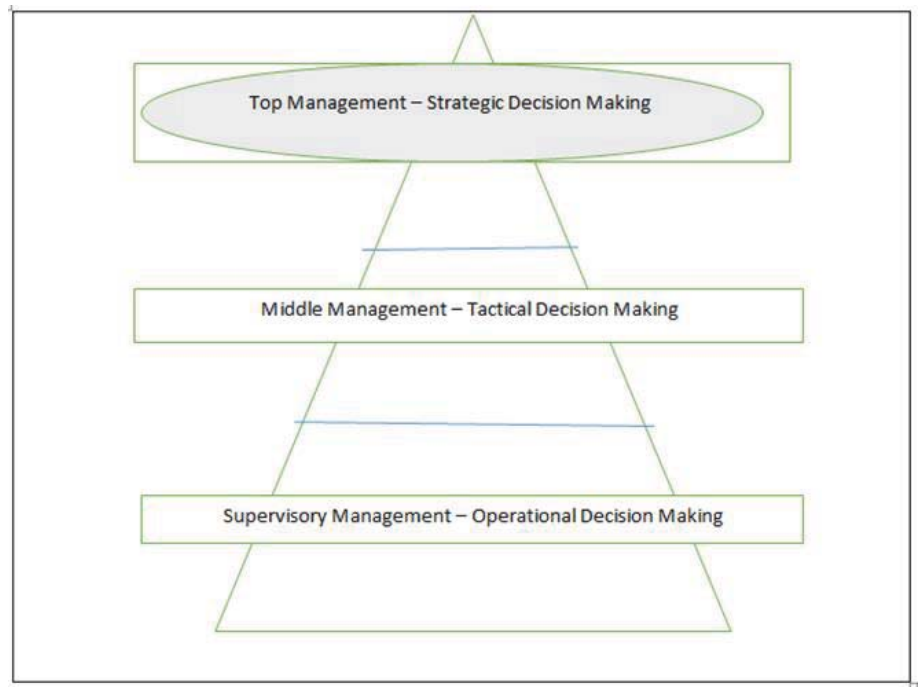

Source: Adapted from Anderson \& Atkins (2001:311)

On the other hand, entrepreneurs are those who take risk and have profitability and growth set as principal objectives. Nieman \& Nieuwenhuizen (2009:13) draw a distinction between entrepreneurial and managerial functions, as well as the difference in expertise and competence required by these individuals. The authors point out that business owner managers are generally those who have planning and market orientation as principal characteristics, whereas entrepreneurs are characterized by an orientation to risk and innovation. Thus, strategic decisions are generally the responsibility of the entrepreneur, who sets strategic objectives in relation to growth targets. Small business owner manager rarely go beyond survival profit and sales targets (Smith \& Chimucheka 2014:162).

In small businesses, strategic decisions are often made by the owner manager. The owner manager is often not an entrepreneur, and experiences difficulties with sound financial management decisions. According to Fatoki (2012:180), most small business owner managers do not provide for the future, and are clueless regarding the notion of capital maintenance. They focus on the daily decisions, mostly involving survival activities. The analytical model for decision making in small businesses developed for this study indicates that the human (decision maker) is at the centre of the process, and provides an explanation of how strategic financial management decisions are made. According to Jocumsen (2004:659), and to Huang (2009:25), successful strategic decision making in small businesses depends on the human's capacity to search for, and analyse the necessary information, as well as the ability to consider relevant surrounding issues. The outcome of the decisions should be measured with reference to the business objectives and the feedback received from other stakeholders (see figure 2).

Small business owner managers generally gather information from a variety of sources: trade journals, management journals, meetings, courses, or an internet search. For example, Pineda et al. (1998:773) show that a search for information will depend on the decision area; when making costing related decisions, decision makers need a greater number of information sources upon which they rely more heavily than when making decisions related to employees or technical aspects. These authors reveal several patterns in the use of both internal information sources (personal judgment) and external sources (advice from experts). Further, they distinguish between two categories of information search: the active search and the passive search.

Jocumsen (2004:659) distinguishes between two categories of financial analysis in small businesses: formal analysis and informal analysis. Formal financial analysis is defined as the financial management learning techniques or competencies used in the decision making process. These techniques or tools are generally written, rational, and measurable. Informal analysis involves inherent techniques or competencies, including intuition, long term thinking, and gut feel. 
Figure 2: Model of the decision making process in small businesses

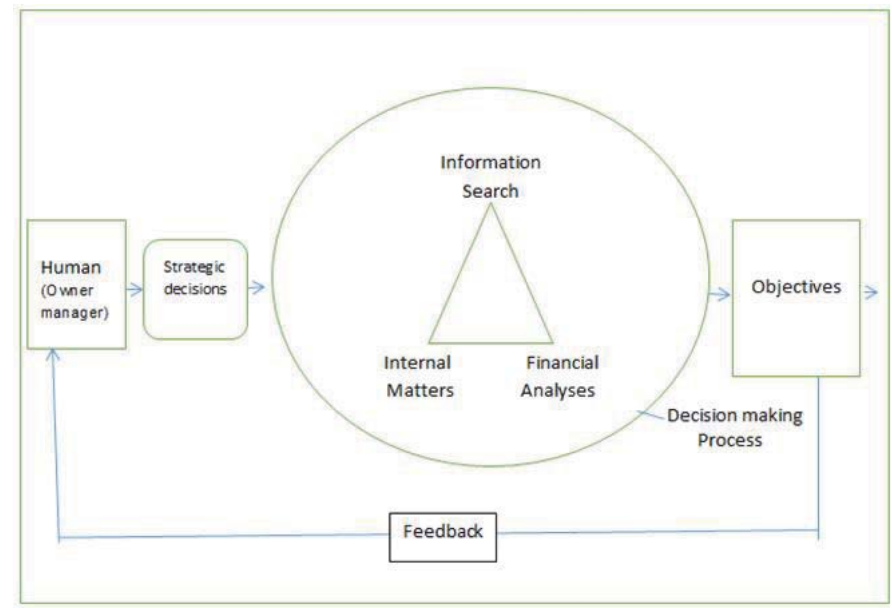

Source: Adapted from Jocumsen (2004:659) and Huang (2009:25)

\subsection{Relevant surrounding issues}

Although financial criteria serve as the principal success indicators in business, there are often non-financial considerations to be taken into account in the process of decision making. McGee and Sawyer (2003:385), for instance, observe the role played by such personal ambitions on the part of small business owner managers as personal lifestyle, feedback, being own boss, independence and social status. Aspects of social responsibility such as job creation and environmental protection play an often-overlooked role too in the process of taking business decisions.

Feedback, according to Frost (2003:49), serves as a tool to evaluate and control the outcomes of decisions. The on-going nature of the decision making process dictates constant monitoring, evaluation, choosing between alternative courses of action, and following up on choices made. In order for the decision maker to evaluate decisions made, there is a need to gather information, for which a formal information recording system is required. Generally, an evaluating system should provide feedback on how the decision is being implemented, what results are obtained, and what adjustments are necessary to enhance those results. This process is possible only with an information recording system in place in the business.

\subsection{The small business}

This article considers the three categories of small business as defined by SEDA: micro enterprises, small enterprises, and medium enterprises (SMMEs). The classification is based on the number of employees considered "regularly" employed, as the table shows below:

Table 1: Small business classification

\begin{tabular}{|c|c|}
\hline Business category & Number of employee \\
\hline Medium & $51-200$ \\
\hline Small & $21-50$ \\
\hline Very small & $5-20$ \\
\hline Micro & $<5$ \\
\hline
\end{tabular}

Source: SEDA Report (2009)

Another source of difficulty in small businesses arises from limited resources. Segbers, Manigari and Vanacker (2012:63) indicate that a lack of access to finance poses a major hurdle for small businesses, compared to the case with big business. As a result, regular professional consultants are unavailable to small business. 


\section{Methodology}

This study employs a survey through which data was collected by means of a structured questionnaire. The questionnaire was self-administered to small business owner managers in the 9 provinces in South Africa. The sample was restricted to those small business owner managers registered with SEDA. The reason for the selection of this business group is the accessibility of the respondents, and the assistance offered by SEDA in channelling the questionnaire to and retrieving the responses from their client back to the researcher afterward. This method of delivery was chosen because the total population of small business owner managers in South Africa is too large for the researcher to have personally covered all owing to time and resource constraints. Convenience sampling was used.

The questionnaires were sent to 250 SMMEs owner managers. Of the 145 questionnaires that were filled up and returned, only 143 were usable, representing a responses rate of $56.8 \%$. The Raosoft sample size calculator was used to determine the sample size, taking into consideration the population size, the margin of error, and the desired confidence level. The SEDA annual report (2009 - 2010:13) indicated that they had some 56054 registered clients (small businesses) at the time, and regularly worked with 23874 of these, of which 11302 were considered active. Given these figures, the Raosoft would have necessitated a sample size of 90 . The actual sample size used was thus way in excess of that recommended by the calculator.

Likert scale questions were used except for demographic questions. The choice of the five-point scale enabled respondents to indicate their views on various aspects of strategic financial management decision making in their businesses. The questions themselves were developed for relevance to the African continent, following an extensive review of the literature. The questionnaire was divided into two sections: biographical questions and questions related to strategic decision making. The statistical analysis was mainly descriptive in nature. A pilot study was conducted on the survey instrument used in this research with 10 small business owner managers in order to ensure face and content validity. Small business owner managers were assured of confidentiality with regard to the data collected. In addition, the reliability of the study was ensured by using Cronbach's alpha. The Friedman test was used to rank the most important strategic financial management decisions according to the methods used. Once the most important of these were known, Fisher's Exact Test was used to determine significance in the relationships between each of these decisions and the owner managers' characteristics.

\section{Results}

The results of the survey are grouped into three sections. The first section analyses small business owner manager characteristics; the second is devoted to the analysis of small business characteristics; the third section presents the strategic financial management decision-making process.

\subsection{Small business owner manager demographic characteristics}

Table 2 below depicts the biographical information of the respondents.

Table 2: Owner manager characteristics in the sample

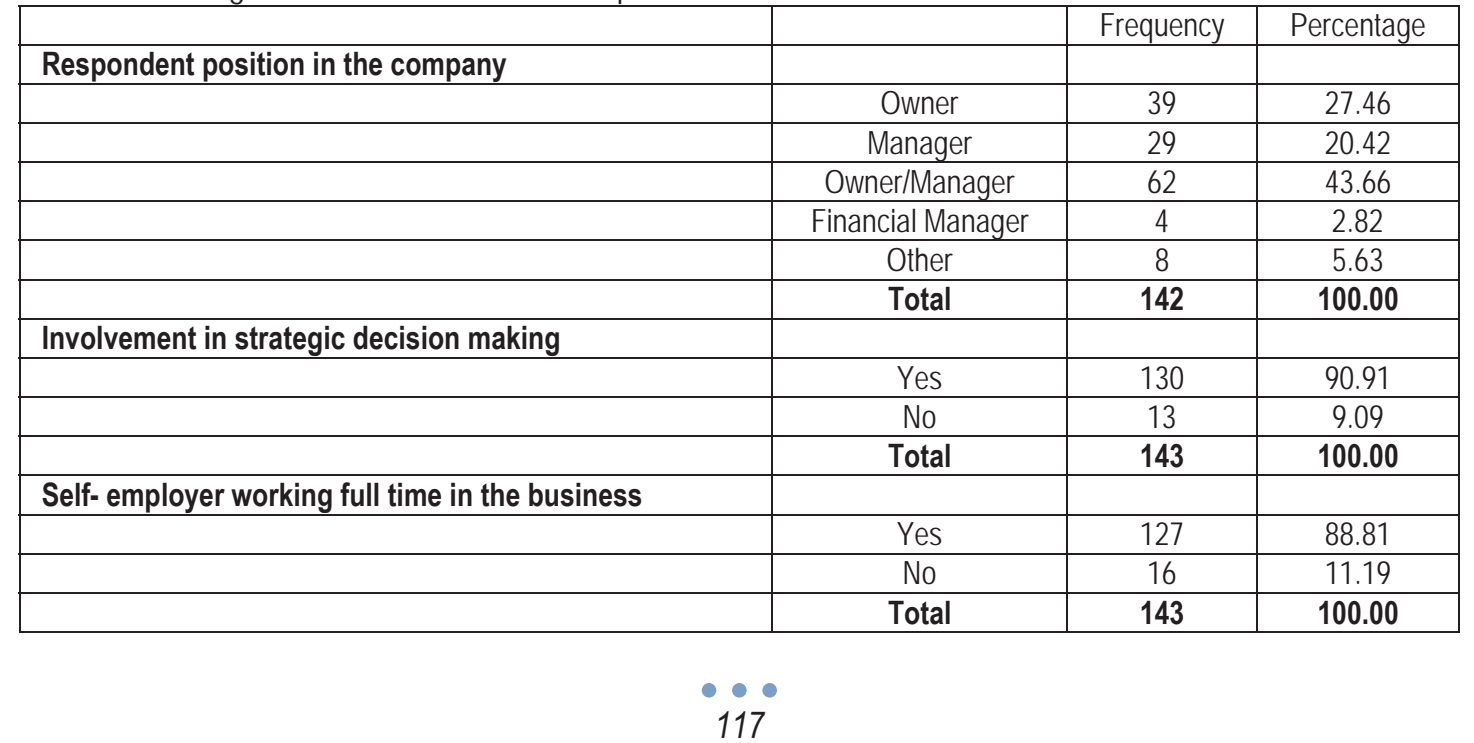




\begin{tabular}{|c|c|c|c|}
\hline Gender & & & \\
\hline & Male & 80 & 55.94 \\
\hline & Female & 63 & 44.06 \\
\hline & Total & 143 & 100.00 \\
\hline \multicolumn{4}{|c|}{ Higher qualification obtained } \\
\hline & Up to matric & 52 & 36.36 \\
\hline & Diploma & 51 & 35.66 \\
\hline & Post diploma & 40 & 27.97 \\
\hline & Total & 143 & 100.00 \\
\hline \multirow[t]{7}{*}{ Years of experience } & & Frequency & Percentage \\
\hline & $1-2$ & 11 & 8.46 \\
\hline & 3 & 21 & 16.15 \\
\hline & $4-5$ & 36 & 14.62 \\
\hline & $6+$ & 52 & 47.69 \\
\hline & Total & 130 & 100.00 \\
\hline & & Frequency & Percentage \\
\hline \multicolumn{4}{|l|}{ Population group } \\
\hline & African & 108 & 75.52 \\
\hline & Asian & 13 & 9.09 \\
\hline & Coloured & 12 & 8.39 \\
\hline & White & 10 & 6.99 \\
\hline \multirow[t]{6}{*}{ Age group (years) } & Total & 143 & 100.00 \\
\hline & $18-24$ & 8 & 5.59 \\
\hline & $25-34$ & 46 & 32.17 \\
\hline & $35-54$ & 88 & 61.54 \\
\hline & $55+$ & 1 & 0.70 \\
\hline & Total & 143 & 100.00 \\
\hline \multicolumn{4}{|c|}{ Financial management training course completed } \\
\hline & Yes & 84 & 58.74 \\
\hline & No & 57 & 39.86 \\
\hline & Total & 140 & 100.00 \\
\hline
\end{tabular}

Source: Data analysis for the study

The statistical data identify the principal factors that influence strategic financial management decisions in terms of the methods used. These methods may be broken down into three different competencies: learned, inherent, and networking.

For the learned competencies, Fisher's Exact Test at the 5\% level of significance suggests that there is no statistically significant relationship between strategic decisions made (investment decisions) and the owner managers' characteristics, except for the owner managers' years of experience, where the P-value is $=0.0200<0.05$.

Table 3: Strategic decisions by learned competencies in terms of respondents' years of experience

\begin{tabular}{|c|c|c|c|c|}
\hline & $1-3$ years & $4-6$ years & $\mathbf{7 + y e a r s}$ & Total \\
\hline Disagree & $4(12.90 \%)$ & $0(0 \%)$ & $0(0 \%)$ & 4 \\
\hline Neutral & $1(3.23 \%)$ & $2(11.76 \%)$ & $1(2.27 \%)$ & 4 \\
\hline Agree & $26(83.87 \%)$ & $15(88.24 \%)$ & $43(97.73 \%)$ & 84 \\
\hline Total & $31(33.71 \%)$ & $17(18.48 \%)$ & $44(47.83 \%)$ & 92 \\
\hline
\end{tabular}

Source: Own data analysis

The respondents were asked, based on their experience in business, to indicate on a rating scale of 1 to 5 if they relied on learned competencies (financial analysis) to make strategic decisions. A rating of 1 to 2 indicated "disagree", a rating of 3 "neutral", and a rating of 4 to 5 indicated "agree". Once the respondents had provided the ratings, the responses were then divided into the following three categories of owner managers' years of experience in business:

- $1-3$ years were classified as new entrepreneurs, just started in business;

- 4-6 years were classified as experienced entrepreneurs; 
- $7+$ years as more experienced entrepreneurs.

Table 3 shows that most of the respondents with less than three years of experience (84\%) tended to agree that learned competencies (financial analysis techniques) had a significant impact on strategic decisions. The $13 \%$ of the respondents with less than three years disagreed, whilst the $12 \%$ of the respondents between 4 to 6 years of experience were neutral. A massive $98 \%$ of the respondents with more than 7 years of experience agreed with the statement. As might have been expected, those with 7 or more years of experience tended to rely on that experience (learned competencies) rather than on intuition (inherent competencies).

For inherent competencies, Fisher's Exact Test at the $5 \%$ level suggests that there is no statistically significant relationship between strategic decisions (e.g. cash flow decisions) and the owner manager's characteristics, except for training, where the $\mathrm{P}$ value for Fisher's Exact Test is $=0.0193<0.05$.

Table 4: Strategic decisions by inherent competencies in terms of training

\begin{tabular}{|c|c|c|c|}
\hline & Yes & No & Total \\
\hline Disagree & $5(6.02 \%)$ & $6(10.91 \%)$ & 11 \\
\hline Neutral & $6(7.23 \%)$ & $12(21.82 \%)$ & 18 \\
\hline Agree & $72(86.75 \%)$ & $37(67.27 \%)$ & 109 \\
\hline Total & $\mathbf{8 3 ( 6 0 . 1 4 \% )}$ & $\mathbf{5 5 ( 3 9 . 8 6 \% )}$ & 138 \\
\hline
\end{tabular}

Source: Own data analysis

The respondents were asked to answer "yes" or "no" to the statement "Have you completed any financial management training course?" By examining their answers, it was possible to infer on the extent of reliance on inherent competencies. Table 4 reveals that most of the respondents tended to agree (87\%) with the statement that their gut feel or intuition guided them when making strategic decisions in their businesses. This suggests that even those with some training $(87 \%)$ were inclined to use gut feel in decision making. For networking competencies, Fisher's Exact Test at the 5\% level of significance suggests that there is no statistically significant relationship between the strategic decisions made and the owner managers' characteristics.

\subsection{Small business characteristics}

Statistical data suggests that there is no relationship between business characteristics of business age, industry sector, gross asset value and annual turnover, on the one hand, and strategic decision making in terms of the owner managers' capacity to choose, anticipate and consider risk, on the other. Thus, business characteristics do not appear to have any significant impact on strategic financial management decision making in small businesses.

\subsection{The financial management strategic decision making process}

The steps followed by small business owner managers in their decision making process can depicted as follows:

- Recognition of a need to make a decision

- Information search

- Information analysis

- Consideration of surrounding issues

- Establish objectives of the strategic decision to make

○ Receive feedback

Each question is structured employing a 5-point agreement Likert scale rating. Respondents were requested to indicate, on a scale rating, the extent of their agreement or disagreement with each statement, with the coding strongly agreed (SA), agreed (A), disagreed (D), strongly disagreed (SD), and unsure or neutral (U). The frequency percentage score is treated as a measure of significance. The responses were separated into three groups using the following criteria:

- Whether small business owner managers understand financial management principles (techniques) and apply them to make strategic decisions. This category of responses comprised decision makers who strongly agreed $(\mathrm{SA})$ and agreed $(\mathrm{A})$.

- Whether small business owner managers understand financial management principles (techniques) but 
choose not to apply them to the decision making process. This category of responses consists of those who strongly disagreed (SD) and disagreed (D).

- Whether small business owner managers do not understand financial management principles (techniques) and therefore cannot use them. This applied to those who were unsure $(U)$.

\subsubsection{The strategic financial management decisions}

Strategic financial management decisions are made of decisions area such as budgeting, capital structure, working capital management (cash flow and inventory decisions), withdrawal decisions, and costing. Table 5 shows extent to which small business owner managers applied the following techniques (practices) to facilitate strategic decisions in their businesses.

Table 5: Financial management practices

\begin{tabular}{|c|l|c|c|c|}
\hline \multicolumn{1}{|c|}{ Statements } & SD / D \% & U \% & A / SA \% \\
\hline 34 & use cash flow statement information for predictions in my business. & 20 & 32.14 & 47.86 \\
\hline 40 & I prefer to borrow than to use own internal funding. & 52.15 & 13.57 & 34.29 \\
\hline 41 & I use the cost of equity to determine the cost of my capital. & 15.71 & 42.14 & 42.15 \\
\hline 47 & I consider tax implications when making investment decisions in my business. & 20.71 & 23.57 & 55.72 \\
\hline 50 & $\begin{array}{l}\text { Small businesses are often likely to wait for cash (internally generated funds) before engaging in } \\
\text { expenditure decisions. }\end{array}$ & 10.71 & 17.86 & 71.43 \\
\hline 53 & $\begin{array}{l}\text { The instability of cash flow in small business makes it difficult to predict the future cash flow in } \\
\text { my organization. }\end{array}$ & 12.14 & 16.43 & 71.43 \\
\hline 54 & My withdrawal pattern is based on own personal needs. & 43.57 & 29.29 & 27.14 \\
\hline 56 & follow the withdrawal pattern for similar businesses in my sector. & 31.43 & 40 & 28.57 \\
\hline 57 & My withdrawal pattern depends on my organization's plan & 7.19 & 27.34 & 72.66 \\
\hline 61 & My customer credit periods help me to determine late payments. & 25 & 27.86 & 49.14 \\
\hline 66 & My capital expenditure decisions are based on business profitability (wait for profit generated). & 5.72 & 12.14 & 82.14 \\
\hline
\end{tabular}

Source: Own data analysis

Some $73 \%$ of the respondents did control their withdrawals based on some organisational plan. The data suggests, however, that most of the respondents (82\%) had difficulties in developing a capital expenditure plan (budget). Most of them based their capital expenditure decisions on the cash generated instead of the cash flow projected or anticipated. This lack of planning for future cash flow explains the waiting for cash (71\%) before carrying out capital budgeting.

Overall, responses in this section also suggest that a significant proportion of respondents were not familiar with financial management techniques or principles developed for sound strategic decisions. "Unsure" responses recorded the following percentages: techniques related to cash flow statement - (32.14\%); cost of equity - (42.14\%); tax implication (23.57\%); withdrawal patterns for similar businesses - (40\%); personal needs evaluation - (29.29\%) and customer credit periods - (27.86\%). These "unsure" responses may in fact point to ignorance.

\subsubsection{Information search}

Table 6 shows responses to statements relating to information search.

Table 6: Information search

\begin{tabular}{|c|l|c|c|c|}
\hline \multicolumn{1}{|c|}{ Statements } & SD / D \% & U \% & A / SA \% \\
\hline 32 & I get my financial information from my bank statement. & 28.58 & 24.29 & 47.14 \\
\hline 42 & I consider my competitor's prices when making costing decisions. & 10 & 20 & 68.89 \\
\hline 52 & My past experiences guide me in making cash flow projections in my business. & 7.86 & 12.86 & 79.29 \\
\hline 58 & $\begin{array}{l}\text { I often rely on a key family member's advice to determine how much funding I need to } \\
\text { withdraw. }\end{array}$ & 51.42 & 14.29 & 34.28 \\
\hline
\end{tabular}

Source: Own data analysis 
Overall, the responses to these statements indicate that most small business owner managers (79\%) based their strategic decisions (cash flow) on a limited (narrow) information search. It is possible that they rely on their experience (personal judgment) when making cash flow decisions. This type of information search is called passive. Relative to costing decisions, a significant group of respondents (69\%) who based their information search on competitors' prices. This form of information search is termed active. These findings are in agreement with results presented by Pineda et al. (1998:2), who argued that most small business owner managers used external sources of information (such as competitors' prices) to make costing decisions in their businesses. They observed that most small business owner managers collected information about competitors indirectly from a number of sources, including customers, suppliers and newspapers.

\subsubsection{Information analysis}

Table 7 reports responses to statements relative to the analysis of information by owner managers.

Table 7: Information analysis

\begin{tabular}{|c|l|c|c|c|}
\hline \multicolumn{1}{|c|}{ Statements } & SD / D \% & U \% & A / SA \% \\
\hline 27 & I make strategic decisions in order to satisfy my own personal needs. & 52.86 & 14.29 & 32.85 \\
\hline 20 & Strategic decision making is a process of making a choice from a number of alternatives. & 12.14 & 14.29 & 73.57 \\
\hline 33 & I often rely on my balance sheet statement when making decisions. & 21.42 & 32.86 & 45.72 \\
\hline 37 & I generally make capital decisions that feel right to me. & 27.15 & 28.57 & 44.28 \\
\hline 39 & I make use of my financial auditing report statements to determine my funding capacity. & 20.71 & 22.86 & 56.43 \\
\hline 46 & I double-check my information sources before making capital budgeting decisions. & 5.72 & 10.71 & 83.57 \\
\hline
\end{tabular}

Source: Own data analysis

Some $83 \%$ of the respondents indicated that they double-checked information before use, pointing to some degree of financial analysis. About a third (33\%) of the respondents were unsure about the use of the Balance Sheet, and only $56 \%$ of the respondents were able to make use of the auditing financial statement to make strategic decisions (funding decisions). Other significant groups of respondents instead relied on personal financial analysis such as aspiration and personal needs. This is in line with an analysis reported by Ghobakhloo et al. (2011:53), who demonstrated that most small business owner managers have been found to use personal rather than impersonal financial analysis. They contend that most small business owner managers rely on intuition (aspiration) and own needs to make strategic decisions (funding decisions).

\subsubsection{Consideration of surrounding issues}

In addition to business objectives and stakeholder feedback, this section deals with the extent to which issues of the environment and social responsibility are considered in the decision making process.

\subsubsection{Objectives}

Table 8 shows the extent to which small business owner managers consider business objectives when making strategic financial management decisions.

Table 8: Objectives of strategic decision making

\begin{tabular}{|l|l|c|c|c|}
\hline \multicolumn{1}{|c|}{ Statements } & SD / D \% & U \% & A / SA \% \\
\hline 25 & make strategic decisions for the sake of growing my business. & 4.28 & 7.14 & 88.57 \\
\hline 26 & I make strategic decisions in my business for the sake of gaining profit. & 8.57 & 18.57 & 72.85 \\
\hline 28 & make strategic decisions for the sake of making money. & 24.28 & 23.57 & 52.14 \\
\hline 31 & Strategic decision-making helps me to solve problems that occur in my community or environment & 17.02 & 22.7 & 60.29 \\
\hline
\end{tabular}

Source: Own data analysis 
Although most small business owner managers (89\%) agree with the statement "I make strategic decisions for the sake of growing my businesses", a significant group of respondents (24\%) were unsure about their main objective in making strategic decisions. This may indicate disconnect between the organization's long-term objectives and the strategic decisions taken.

\subsubsection{Feedback}

Table 9 concerns the incorporation of stakeholder feedback in decision making.

Table 9: Feedback analysis

\begin{tabular}{|c|c|c|c|c|}
\hline Statements & SD / D \% & U \% & A / SA \% \\
\hline 35 & My business does not need a traceable information recording system. & 27.86 & 12.86 & 59.29 \\
\hline 49 & usually consider the requests of my customers concerning investment in new products and services. & 8.57 & 12.14 & 79.28 \\
\hline
\end{tabular}

\section{Source: Own data analysis}

Most respondents heed requests and suggestions from customers (79\%) in their investment decisions. This consideration could possibly stem from the African notion Ubuntu (sharing). Feedback may also be gathered from recorded information in the monitoring and evaluation processes, when deemed adjustments are introduced. On this aspect, some $59 \%$ of the respondents indicate an interest in an information recording system. This is line with Frost's analysis (2003:49), in which he observes that the monitoring and recording of information relative to competitors is not available to small businesses, owing to a lack of strategic thinking.

\section{Discussion}

The overall findings in this article indicate that strategic financial management decision making is a complex phenomenon to South African small business owner managers. The human (decision maker), at the centre of the decision making process, is unfamiliar with the theoretical sequence of steps necessary for effective decision making. Searching for information, analysing it, and considering the risks involved and options available form part of this sequence.

As a result, strategic financial management decision making in small business hinges not only on owner managers' experience from time spent in business, but also on sheer intuition and gut feel (figure 3 below).

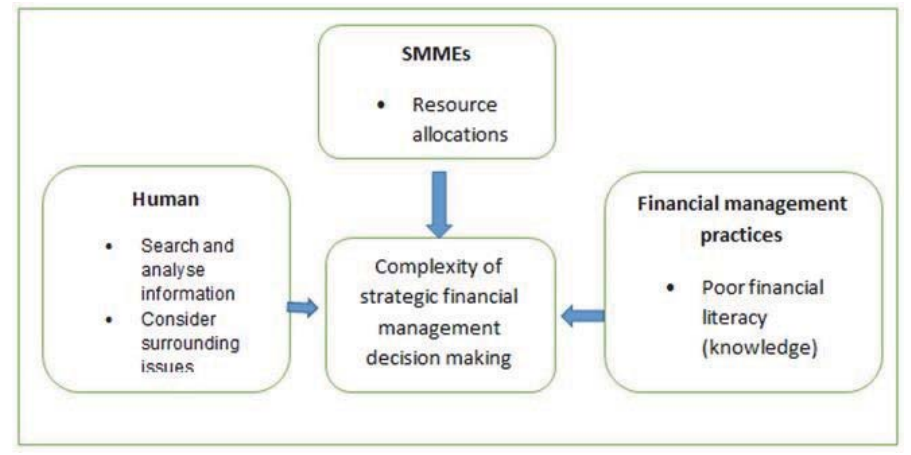

\section{Limitations of the Study}

There was a limitation regarding the target population group, which was not representative of the entire population of SMMEs in South Africa. The respondents who took part in this study were those registered with, and considered active by SEDA in the 9 provinces of South Africa. The study further concerns the small business sector only, excluding big business and the corporate sector. Thirdly, the study limits itself to only the financial management aspects of the small business, precluding other functions such as marketing, human resource, or production, for instance. Lastly, the study limits itself to those decisions deemed strategic, to the exclusion of others such as operational and tactical decisions. 


\section{Conclusion and Recommendations}

This article describes the factors inhibiting efficient and effective strategic financial management decisions in South African small business. The results indicate that the important inhibiting factors are related to owner managers themselves. There is an apparent lack of theoretical knowledge relating to the gathering and analysing of information requisite for effective strategic decisions, and a tendency is suggested on their part to rely on intuition and experience alone.

This study contributes to the academic field of strategic financial management decision making and small business management through a suggestion as to the reasons for unsound strategic decisions in small business. This problem is significant, but surprisingly largely ignored in current strategic literature. Much of the literature has tended to focus on describing how small businesses function. Limited attention has been given to this special problem, compounded by a scarcity of empirical data on how these small businesses arrive at strategic decisions. Much of the knowledge to date pertains to large firms.

A possible solution to the problem lies in mentorship, partnership, or coaching, and possibly a provision of financial literacy education to small business owner managers. For future research, it would be useful to extend the number of SMMEs involved in this study, to obtain a sample more representative of the universe of small business in South Africa.

\section{References}

Anderson, A.R. \& Atkins, M.H. (2001). Business strategies for entrepreneurial small firms. Strategic Change, 10 (6):311-324.

Agyei-Mensah B.K. (2011). Financial management practices of small firms in Ghana: an empirical study. African Journal of Business Management, 5(10):3781-3793.

Ang, J. (1992). Small business uniqueness and the theory of financial management. The Journal of Small Business Finance, 1:185-203.

Botha, M. \& Esterhuyzen, E. (2013). The perceived capabilities and willingness of South African small business owners to act as business mentors. African Journal of Business Management, 7(5): 331-343.

Chimucheka, T. (2014). Entrepreneurship education in South Africa. Mediterranean Journal of Social Science, MCSER Publishing, Rome-Italy, 5(2):403-416.

Chimucheka, T. (2014) Entrepreneurship, economic growth and entrepreneurship theories. Journal of Social Science, MCSER Publishing, Rome-Italy, 5(14):160-168.

Department of trade and industry (2003). Government Gazette, www.thedti.gov.za/business regulation/docs/nla/ [Accessed: 15 May 2012].

Ekanem, I. (2005). Bootstrapping: the investment decision - making process in small firms. The British Accounting Review, 37 (3):299318.

Fatoki, O. (2012). An investigation into the financial management practices of new Micro - enterprises in South Africa. Journal of Social Sciences, 33(3):179-188.

Fatoki, O. (2014). Student entrepreneurs on university campus in South Africa: motivations, challenges and entrepreneurial intention. Mediterranean Journal of Social Sciences, MCSER Publishing, Rome-Italy, 5(16):100-107.

Fatoki, O. \& Chiliya, W. (2012). An investigation into the attitudes toward business ethics and corporate social responsibility by local and immigrant SME owners in South Africa. Journal of Social Sciences, 32(1):13-21.

Frost, F.A. (2003). The use of strategic tools by small and medium-sized enterprises: an Australasian study. Strategic Change, 12(1):4962.

Ghobakhloo, M., Sadegh, M., Sai, T., \& Zulkifli, N. (2011). Information technology adoption in small and medium-sized enterprises; an appraisal of two decades literature. Interdisciplinary Journal of Research in Business, 1(7):53-80.

Harif, M. A., Osman, H. B., \& Hoe, C. H. (2010). Financial management practices: an in-depth study among the CEOs of Small and Medium Enterprises (SMEs). International Review of Business Research Papers, 6(6):13-35.

Huang, X. (2009). Strategic decision making in Chinese SMEs. Chinese Management Studies, 3(2):87-101.

Jocumsen G. (2004). How do small businesses managers make strategic marketing decisions? European Journal of Marketing, 38 (5/6):659-674.

Liberman - Yaconi, L. Hooper, T. \& Hutchings, K. (2010). Toward a model of understanding strategic decision making in micro - firms: exploring the Australian information technology sector. Journal of Small Business Management, 48(1):70-95.

Mair, J. \& Thompson (2009). The UK association conference attendance decision-making process. Tourism management, 30(3):400409.

McMahon, R.G.P., Holmes, S., Hutchinson, P.J., Forsaith, D.M. (1993). Small enterprise financial management. Theory and Practice, Harcourt Brace: Sydney.

McMahon, R.G.P. (1998). Business growth and performance and the financial reporting practices of Australia manufacturing SMEs. Doctoral thesis, the University of New England: NSW, Australia.

McGee, J.E. \& Sawyer, O.O. (2003). Uncertainty and information search activities: a study of owner-managers of small high-technology manufacturing firms. Journal of Small Business Management, 41(4):385 - 402. 
Nieman, G. \& Neuwenhuizen, C. (2009). Entrepreneurship: A South Africa perspective. Pretoria: Van Schaik.

Nieman, G. \& Pretorius, M. (2004). Managing growth. A guide for entrepreneurs. Cape Town: Juta and Co Ltd.

Neneh, N.B. (2012). An exploratory study on entrepreneurial mindset in the small and medium enterprise (SME) sector: A South African perspective on fostering small and medium enterprise (SME) success. African Journal of Business Management, 6(9): 33643372.

Netswera, F.G. (2001). Perceptions of Johannesburg small business operators about their small business support systems. South African Journal of Business Management, 32(4): 31-37.

Olawale, F. \& Garwe, D. (2010). Obstacles to the growth of new SMEs in South Africa: A principal component analysis approach. African Journal of Business Management, 4(5): 729-738.

Orobia, L.A., Byabashaija, W., Munene, J.C., Sejjaaka, S.K., \& Musinguzi, D. (2013). How do small business owners manage working capital in an emerging economy? A qualitative inquiry. Qualitative Research in Accounting \& Management, 10(2):127-143.

Perks, S. (2010). Problem-solving techniques of growing very small businesses. Journal of Enterprising Communities: People and Places in the Global Economy, 4(3):220-233.

Pineda, C.R., Lerner, D.L., Miller, C.M. \& Philipps, J.S. (1998). An investigation of factors affecting the information-search activities of small business managers. Journal of Small Business Management, 36(1):60-72.

RAOSOFT (2009). Sample size calculator (online) available http://www.raosoft.com/samplesize.html [Accessed: 15 May 2012].

Ross, S.A.,Westerfield, R.W. \& Jaffe, J. (1999). Corporate Finance. 5th edition, Irwin and McRaw-Hill, Boston.

Seda Annual Reports (2008-09). http://www.seda.org.za [Accessed: 15 May 2012].

Segbers, A.; Manigari, S. \& Vanacker, T. (2012). The impact of the human and social capital on entrepreneurs' knowledge of finance alternatives. Journal of Small Business Management, 50(1):63-86.

Smith, W., \& Chimucheka, T. (2014). Entrepreneurship, economic growth and entrepreneurship theories. Mediterranean Journal of Social Sciences, 5(14):160-165.

Sunday, J.K. (2011). Effective working capital management in small and medium scale enterprises (SMEs). International Journal of Business and Management, 6(9):271-278. 